\title{
BEHAVIOURAL ADAPTATION OF JAPANESE QUAIL TO THE REPEATED SHORT-TERM MICROGRAVITY INDUCED BY PARABOLIC FLIGHTS
}

\author{
B. BILČfK ${ }^{1}$, K. BOḊA ${ }^{1}$, L. KOŠTÁL ${ }^{1}$, J. SÝKORA ${ }^{2}$, M. JURÁNI $^{1}$, V. SABO ${ }^{1}$ \\ ${ }^{1}$ Institute of Animal Biochemistry and Genetics, Slovak Academy of Sciences, 90028 Ivanka pri Dunaji, \\ Slovak Republic \\ ${ }^{2}$ Center for Study of Stress, Czech Academy of Sciences, Prague, Czech Republic
}

Received July 7, 1995

Accepted June 6, 1996

\begin{abstract}
Bilčík B., K. Boda, L. Koštál, J. Sýkora, M. Juráni, V.Sabo:Behavioural Adaptation of Japanese Quail to the Repeated Short-term Microgravity Induced by Parabolic Flights. Acta vet. Brno 1996,65: 73-75.

Behavioural adaptation of adult Japanese quail to the repeated short term microgravity induced by parabolic flights was studied. Two lines of quail - the line genetically selected for resistance to hypodynamy and the randombred control line - were compared. Birds were subjected to the series of five flights repeated in 24-hour intervals. During each flight the state of microgravity lasting 15 to 20 seconds was induced 11 times. Differences in behaviour between lines as well as between sexes were analysed. Adult Japanese quail adapted relatively quickly to the short-term microgravity. The adaptation process seemed to be strongly influenced by the genetic background and sex.
\end{abstract}

Japanese quail, sex, parabolic flight, behaviour, adaptation

Presented paper is a part of series of experiments studying possibilities of long-term stays of Japanese quail, as one of elements of an autonomous closed ecosystem, on cosmic orbital complexes and planetary stations. Final goal of all these experiments is to provide a life support for long-stays of man in these conditions. Within this project ontogeny ( $\mathrm{Meles}$ ko et al. 1991; B od a et al. 1991), as well as endocrine ( $V$ ý b o h et al. 1993) and behavioural (Koštál et al. 1993) reactions of Japanese quail to the microgravity conditions were studied aboard the MIR orbital station. In all above mentioned experiments quail from the line genetically selected for the resistance to hypodynamy (simulated microgravity) were used ( Juráni et al., in this volume).

As it was shown in previous experiments, quail hatched aboard the MIR station had problems with motor coordination and control of movement direction under microgravity conditions (Košt ál et al. 1993). Due to these problems hatchlings were not able to reach the feeder in the ,Nest“ device, technology designed for keeping quail during space flights, i.e. were not self-sufficient. Adult quail, hatched on earth with normal gravity conditions, had less problems with motor coordination during the space flight (Ko š ál et al. 1993).

The aim of the presented paper was to study the behavioural adaptation of quail to microgravity, in order to get more information for future design of technology for keeping quail in space. For induction of repeated short-term microgravity parabolic flights were used. Microgravity state is induced in the push-over phase of the flight pattern of the aeroplane flying a Keplerian parabolic trajectory. Duration of a microgravity state depends on type of aircraft and can vary from 10 to 45 seconds (O osterveld and Greven 1975).

Because of small number of animals used in experiment ( 8 birds in total), our data do not meet the criteria of systematic behavioural observation required for quantitative analysis. Presented results are therefore preliminary and are based on qualitative description of behaviour only. 


\section{Materials and Methods}

Behavioural adaptation of two lines of Japanese quail (Coturnix coturnix japonica) - line selected for 12 generations for resistance to hypodynamy ( Juráni et al. 1988) and randombred control line - was compared. From each line four adult birds (two females and two males) were tested. Each bird was individually marked with a numbered wingtag.

The test box had similar size and shape as the „Nest“ device, used for keeping quail aboard the MIR orbital station (Boda et al. 1991). It consisted of a transparent plexiglass cylinder with the diameter $32 \mathrm{~cm}$ and perforated walls. A mirror placed under $45^{\circ}$ angle over the testing arena allowed simultaneous observation of birds from front and from above. Test box was affixed in the central part of the aeroplane. Behaviour of birds was recorded on videotape.

Birds from each line were subjected to five testing flights, performed during five subsequent days. The microgravity state was induced 11 times during each flight. Duration of single microgravity state was 15 to 20 seconds, with 20-30 seconds intervals between inductions. During each flight, 2 males and 2 females from to the same genetic line were placed in the testing arena and tested together.

\section{Results and Discussion}

Repeated parabolic flights allowed us to follow the changes of quail behaviour in time and to compare selected and control lines. Although the duration of single microgravity state was rather short, each quail was exposed to it 55 times.

There were clear differences in behaviour between lines. Lowering the g-force evoked flight movements in all birds. However, birds from the line resistant to hypodynamy stopped to spread wings already after the 7 short-term microgravity states and were ,suspended" in the air with folded wings. Birds from the control line seemed to be more stressed by repeated microgravity. Although with increasing number of microgravity inductions there were signs of behavioural adaptation also in controls, adaptation process was less rapid in comparison to hypodynamy resistant line. Quail from the control line were spreading their wings and attempting to fly with various intensity throughout all five successive flights.

Apparent between sex differences in behaviour were also recorded. Females were able to keep balance and orientation better than males. Males reacted in majority of cases by stretching the neck back (extensor reaction) and random movements of the head accompanied by tumbling backwards.

Behavioural changes reported here, i.e. „,suspension“ and extensor reaction, are in agreement with observations described by Kata ye v-S myk (1974) and Oosterveld and Greven (1975). Adult Japanese quail adapts relatively quickly to the short-term microgravity. The adaptation process seems to be strongly influenced by genetic background and sex. However, further experiments, enabling more detailed quantitative analysis, are expected to prove these results and bring more detailed information.

\section{Behaviorálna adaptácia prepelice japonskej na podmienky simulovanej beztiaže indukovanej parabolickými letmi}

Cielom náŠho experimentu bolo štúdium procesu adaptácie prepelice japonskej na opakovaný krátkotrvajúci stav beztiaže, indukovaný parabolickými letmi. Porovnávané boli dve línie prepelice - línia selektovaná na rezistenciu voči hypodynamii a kontrolná linia. Osem vtákov bolo podrobených sérii piatich parabolických letov, opakovaných v 24 hodinových intervaloch. Počas každého letu bol stav beztiaže ( $v$ dížke 15-20 sekúnd) indukovaný 11 krát. Analyzované boli rozdiely v správaní oboch línií ako aj rozdiely medzi pohlaviami. Dospelé prepelice japonské, $\mathrm{z}$ línie selektovaných na rezistenciu voči hypodynamii, sa na krátkodobý stav beztiaže adaptovali pomerne rýchlo. Proces adaptácie móže byt výrazne ovplyvnený genetickým pozadím, ako aj pohlavím. 


\section{Бихевиоральное приспособление японской перөпелки к условиям моделированного состояния невесомости, индуцированного параболическими полетами}

Цель нашего эксперимента сводилась к изучению процесса приспособления японской перепелки к кратковременному повторному состоянию невесомости, индицированному параболическими полетами. Проводили сравнения двух линий перепелок - селектированной по отношению к устойчивости к гиподинамии и контрольной. Восемь птиц проходили серией пяти параболических полетов, повторяемых в суточных интервалах. В ходе каждого полета существовало состояние невесомости (продолжительносью 15 - 20 секунд), индуцированное в одиннадцать раз. Анализировали разницу поведения обеих линий, а также разницу полов. Взрослые японские перепелки линии, селектированной по отношению кустойчивости к гиподинамии, приспособлялись сравнительно быстро к ктатковременному состоянию невесомости. Напроцесс приспособления может оказывать существенное влияние генетический фон, а также пол.

\section{References}

BODA, K., MELESHKO, G. I., SABO, V., SHEPELEV, Ye. Ya., GURYEVA, T. S. JURÁNI, M., KOŠTÁL, L. 1991.:The Physiologist 34: 59-61

JURÁNI, M., BODA, K., KOSTTÁL, L. 1988:The Physiologist 31: 140-141

KATAYEV-SMYK, L.A. 1974: In V. V. Parin (ed.), Nevesomost, Medicina, Moskva, pp. 41-65

KOSTTÁL, L., BILČ́K, B., JURÁNI, M., BOḊA, K., SHEPELEV, Ye. Ya., GURYEVA, T. S., SABO, V., ŚOLCOVA,, I., SYYKORA, J.1993:The Physiologist 36:S50-S52

MELESHKO, G. I., SHEPELEV, Ye.Ya., GURYEVA, T. S. et al. 1991: Cosmic Biol. and Aviacosmic Med., 1:37-39

OOSTERVELD, W. J., GREVEN, A. J.1975: Acta Otolaryngol. 79: 233-241

VÝBOH, P., JURÁNI, M., BOD̉, K., DADASHEVA, O. A., GURYEVA, T. S.1993: Acta vet. Brno, Suppl. 6, 62:S73-S74 